\title{
Association between air pollution in Lima and the high incidence of COVID-19: findings from a post hoc analysis
}

Bertha V. Vasquez-Apestegui ${ }^{1,2 *}$, Enrique Parras-Garrido ${ }^{1}$, Vilma Tapia', Valeria M. Paz-Aparicio ${ }^{1}$, Jhojan P. Rojas ${ }^{3}$, Odón R. Sanchez-Ccoyllo ${ }^{4}$ and Gustavo F. Gonzales ${ }^{1}$

\begin{abstract}
Background: Coronavirus disease 2019 (COVID-19) originated in the People's Republic of China in December 2019. Thereafter, a global logarithmic expansion of cases occurred. Some countries have a higher rate of infections despite the early implementation of quarantine. Air pollution might be related to high susceptibility to the virus and associated case fatality rates (deaths/cases*100). Lima, Peru, has the second highest incidence of COVID-19 in Latin America and also has one the highest levels of air pollution in the region.

Methods: This study investigated the association of levels of PM2.5 exposure in previous years (2010-2016) in 24 districts of Lima with cases, deaths and case fatality rates for COVID-19. Multiple linear regression was used to evaluate this association controlled by age, sex, population density and number of food markets per district. The study period was from March 6 to June 12, 2020.

Results: There were 128,700 cases in Lima and 2382 deaths due to COVID-19. The case fatality rate was 1.93\%. Previous exposure to $\mathrm{PM}_{2.5}(2010$-2016) was associated with the number of COVID-19- cases $(\beta=0.07 ; 95 \% \mathrm{Cl}$ : $0.034-0.107)$ and deaths ( $\beta=0.0014 ; 95 \%$ Cl: $0.0006-0.0 .0023$ ) but not with the case fatality rate.

Conclusions: After adjusting for age, sex and number of food markets, the higher rates of COVID-19 in Metropolitan Lima are attributable to the increased $\mathrm{PM}_{2.5}$ exposure in the previous years, among other reasons. Reduction in air pollution from a long-term perspective and social distancing are needed to prevent the spread of virus outbreaks.
\end{abstract}

Keywords: Air pollution, Social distancing, Particulate matter, Long-term exposure, Fatality rate

\footnotetext{
* Correspondence: bertha.vasquez.a@upch.pe

${ }^{1}$ High-Altitude Research Institute; Laboratories of Investigation and

Development (LID), Department of Biological and Physiological Sciences,

Faculty of Sciences and Philosophy, Universidad Peruana Cayetano Heredia,

Av. Honorio Delgado 430, Lima, Peru

${ }^{2}$ Laboratory of Endocrinology and Reproduction, Universidad Peruana

Cayetano Heredia, Av. Honorio Delgado 430, Lima, Peru

Full list of author information is available at the end of the article
}

(c) The Author(s). 2021 Open Access This article is licensed under a Creative Commons Attribution 4.0 International License, which permits use, sharing, adaptation, distribution and reproduction in any medium or format, as long as you give appropriate credit to the original author(s) and the source, provide a link to the Creative Commons licence, and indicate if changes were made. The images or other third party material in this article are included in the article's Creative Commons licence, unless indicated otherwise in a credit line to the material. If material is not included in the article's Creative Commons licence and your intended use is not permitted by statutory regulation or exceeds the permitted use, you will need to obtain permission directly from the copyright holder. To view a copy of this licence, visit http://creativecommons.org/licenses/by/4.0/. The Creative Commons Public Domain Dedication waiver (http://creativecommons.org/publicdomain/zero/1.0/) applies to the data made available in this article, unless otherwise stated in a credit line to the data. 


\section{Background}

Coronavirus disease 2019 (COVID-19), which is caused by severe acute respiratory syndrome corona virus 2 (SARS-CoV-2), was first reported in December 2019 in Wuhan in Hubei Province of the People's Republic of China [1]. On March 11, 2020, due to the global logarithmic expansion of cases, COVID-19 was declared a pandemic by the World Health Organization (WHO) [2]. On March 6, 2020, the Peruvian president announced the first case of COVID-19 infection in Lima - an imported case of a Peruvian national who had returned from recent travel to France, Spain, and the Czech Republic [3]. On March 11, 2020, the president declared a general quarantine with social distancing interventions, including closures of all educational institutions (i.e., schools and universities) in Peru; on March 16, 2020, a national emergency was declared [3].

Three months after the declaration of the emergency and strict measures of social isolation, rates of infection were extremely higher in the metropolitan area of Lima than in the rest of the country. As of June 12, 2020, there were 128,700 (58.3\%) COVID-19 cases in Lima and $92,049(41.7 \%)$ in the rest of the country. Several reasons have been suggested to explain the high incidence of COVID-19 and the inability to reduce the scaling up of the COVID-19 outbreak.

A similar situation with a high incidence of the outbreak in one specific region that was different from that in other regions has been described in Italy, where the highest incidence of COVID-19 was observed in the northern part of the country $[4,5]$.

Several studies have explored the association between viral transmission and the COVID-19 mortality rate with environmental factors, including air pollution $[6,7]$.

One explanation of the higher rate of viral infection is that the susceptibility of the population to the virus is predetermined by exposure to air pollutants in previous years [6]. Similarly, a higher rate of infection with COVID-19 in northern Italy was apparently related to the highest levels of air pollution in that part of the country [8]. It is suspected that individuals with chronic $\mathrm{PM}_{2.5}$ exposure have progressive and chronic inflammation of the respiratory tract and are more prone to severe respiratory diseases after viral infections [4]. Indeed, epidemiological evidence associates chronic $\mathrm{PM}_{2.5}$ exposure with health problems [9-11]. Nonetheless, in a recent study, researchers did not observe an association between $\mathrm{PM}_{2.5}$ exposure and COVID-19 transmission during the first months of the pandemic [12].

Lima is one of the most polluted cities in Latin America [13], and it is possible that long-term exposure to air pollutants may increase infection susceptibility of individuals to different external agents, including bacteria and viruses [14-16]. In the city of Lima, $\mathrm{PM}_{2.5}$ concentrations vary by seasonality based on meteorological conditions. In late autumn and winter (lower temperatures), gas-particle conversion processes increase environmental $\mathrm{PM}_{2.5}$ concentrations [17]. Another possibility is that the virus may be adhered onto particulate matter (PM), which then acts as a vector for spread, extending the persistence of viral particles in the air and thereby favoring "indirect" transmission in addition to direct spread (individual to individual) [5].

Based on these arguments, it has been suggested that the reduction in air pollution that occurred secondary to the shutting down of national and international transportation might reduce spread of the disease $[18,19]$ and thus may explain the decreased incidence of COVID-19.

Experience in Peru seems to demonstrate that the reduction in air pollution was unassociated with the reduction in COVID-19 cases. The daily $\mathrm{PM}_{2.5}$ concentrations showed a gradual decrease from March 16 and did not exceed the environmental quality standards for air that were specified by the Peruvian Ministry of the Environment. On average, a 38\% decrease in $\mathrm{PM}_{2.5}$ was recorded (during the first 15 days of the state of emergency) for Lima compared to its historical concentrations (2015-2019) [20]. However, in the same period, cases of COVID-19 in Lima (1338 × 100,000 inhabitants) increased much more than in the rest of the country $(399 \times 100,000$ inhabitants), representing $58 \%$ of cases countrywide.

Unlike other governments in the world, the Government of Peru declared quarantine as soon as the first case was detected. After declaration of the emergency, the level of air pollutants was greatly reduced, though new cases of COVID-19 continued to increase.

We hypothesized that air pollution might have a chronic effect that increases the susceptibility of individuals to the virus and that individuals living in locations with high air pollution in the years preceding the pandemic are at a higher risk of infection.

To evaluate this hypothesis, this study involved analysis of data from 24 districts of Lima that were characterized by different levels of $\mathrm{PM}_{2.5}$ exposure in the years preceding the COVID-19 outbreak. We sought to evaluate whether the values obtained in previous years were associated with the incidence and mortality rates of COVID-19.

The primary objective was to determine whether longterm exposure to different $\mathrm{PM}_{2.5}$ concentrations is associated with the number of cases, deaths and case fatality rates of COVID-19. Then, we determined whether this association was modified by age, sex, and number of food markets per district. This study is different from numerous other papers that discuss the association between current pollution levels and pandemic intensity. 


\section{Methods}

This cross-sectional study assessed the association between air pollution and the high incidence of COVID-19 in Lima and was undertaken as an ecological study involving analysis of two secondary databases. We assessed data for COVID-19 cases and deaths that occurred in the Lima metropolitan area until June 12, 2020. We comparatively analyzed data on COVID-19 using the estimated daily levels of $\mathrm{PM}_{2.5}$ measured in the years between 2012 and 2016 [21].

Previously, $\mathrm{Vu}$ et al. [21] employed the total number of daily ground $\mathrm{PM}_{2.5}$ measurements obtained from ten monitors in the Servicio Nacional de Meteorología e Hidrología del Perú (SENAMHI) network and six Johns Hopkins University monitoring sites from March 2010 through December 2016. Data accounted for $19 \%$ of the days where any monitor recorded a measurement on a given day. Consequently, daily ambient $\mathrm{PM}_{2.5}$ concentrations from March 2010 to December 2016 were estimated by a random forest (RF) model developed by $\mathrm{Vu}$ et al. [21]. The RF model calibrated satellite aerosol optical depth (AOD), meteorological parameters from chemical transport models, and land use variables with available ground measurements from the two monitoring networks (SENAMHI and Johns Hopkins). For this study, we obtained the annual mean value of $\mathrm{PM}_{2.5}$ from 2012 and 2016, and then we obtained an average value of these five-year periods (Supplementary Table 1). We also included data on temperature and relative humidity.

The district was taken as the unit of analysis. In this study, 24 districts of Lima were included: Ate, Barranco, Carabayllo, Chorrillos, Comas, El Agustino, Independencia, La Molina, La Victoria, Lima, Lince, Los Olivos, Puente Piedra, Rímac, San Borja, San Isidro, San Juan de Lurigancho, San Juan de Miraflores, San Luis, San Martín de Porres, Santiago de Surco, Surquillo, Villa el Salvador, and Villa María del Triunfo. These districts included a total population of 7,029,238 inhabitants and a population density of 241,623 people per square kilometer.

$\mathrm{PM}_{2.5}$ data were obtained from the National Meteorology and Hydrology Service of Peru (SENAMHI), which has ten stations that record $\mathrm{PM}_{2.5}$ daily concentrations in Lima. Data were obtained through an agreement between SENAMHI and Universidad Peruana Cayetano Heredia as part of the Regional GEOHealth Hub centered in Peru. Details of the construction of the database were published previously [21]. Other pollutants were not included because there were insufficient districtlevel data for analysis.

Data on the population and surface areas of the provinces and elevation of the capitals of the provinces in
Peru were obtained from the Peruvian Center for planning website (https://www.ceplan.gob.pe/informacionsobre-zonas-y-departamentos-del-peru/).

In the 24 districts, there were 94,273 COVID-19 cases and 1987 deaths. The case fatality rate due to COVID19 was $2.58 \%$ in Peru and $1.93 \%$ in Lima. There were 948 food markets in the 24 districts of Lima (Peru). Data from the COVID-19 database of the Open Data website of Peru (https://www.datosabiertos.gob.pe/group/datosabiertos-de-covid-19) were used to analyze the information on COVID-19 deaths and COVID-19 cases.

\section{Statistical analysis}

Data were managed in the MS Excel 2016 program. The STATA v14.0 statistical package (StataCorp, College Station, TX, USA) was used for analysis and ArcGIS 10.5 for map construction. First, the average amounts of $\mathrm{PM}_{2.5}$ were calculated for each district from 2012 to 2016 (Supplementary Table 2). Data on age at infection and at death are presented as the mean \pm standard deviation, and differences between the pair of means were calculated by Student's $t$-test. The number of COVID-19 cases and deaths by each district was evaluated overall and by sex.

We explored distinct linear models to assess the relationship of the reported cases and deaths by sex and the sex ratio at the district level in the province of Lima.

As a secondary objective, we assessed the association between the number of food markets per district and cases and deaths due to COVID-19. Data from the number of food markets in each district were obtained from a survey in 2016 (www.inei.gob.pe/media/ MenuRecursivo/publicaciones_digitales/Est/Lib1447/ libro.pdf).

The associations between COVID-19 cases, deaths due to COVID-19 and case fatality rates (deaths/cases of COVID-19*100) and previous $\mathrm{PM}_{2.5}$ exposure were evaluated by using linear regression controlled by age, sex, population density and number of food markets per district. Ambient temperature and relative humidity were also controlled in the analysis. Statistical significance was considered at $p<0.05$.

\section{Results}

By June 12, 2020, Peru had 220,749 COVID-19 cases and 6308 deaths. Lima had 128,700 COVID-19 cases and 2382 deaths. Among all identified COVID-19 cases and deaths, $59.1 \%(N=130,462)$ and $71.1 \%(N=4485)$, respectively, were men. The number of deaths in the 24 districts studied represents $94.8 \%$ of all COVID-19related deaths in Lima.

The COVID-19 case fatality rate was $2.58 \%$ nationwide and $1.93 \%$ for Lima. The mean age at infection was 20 years younger than the age at death due to COVID- 
19. The patterns in the country and Lima Metropolitan area were similar. Women became infected and died at later ages than men (Table 1).

The mean concentrations of $\mathrm{PM}_{2.5}$ from 2012 to 2016 for the 24 districts evaluated in this study are shown in Fig. 1A, whereby the lighter red zone refers to lower levels of PM and the darkest tone to the highest level.

The incidence of COVID-19 cases and deaths are shown in Fig. $1 \mathrm{~B}$ and $\mathrm{C}$, respectively. The highest incidence of cases and deaths occurred in districts located to the north of the city. The COVID-19 case fatality rates (Deaths/Cases*100) in Lima are shown in Fig. 1D, and the abundance of food markets per district is illustrated in Fig. 1E. Moreover, the largest numbers of markets were found in districts with the highest COVID-19 incidence of cases and deaths (northern part of the city).

Higher $\mathrm{PM}_{2.5}$ levels were associated with a higher incidence of COVID-19 cases and deaths in 24 districts of Metropolitan Lima (Fig. 2A and B). However, the case fatality rate did not increase with increasing levels of $\mathrm{PM}_{2.5}$ (Fig. 2C).

Similarly, a higher number of food markets was linearly associated with a higher number of COVID-19 cases and mortality $(p<0.01$, Fig. $3 \mathrm{~A}$ and $p<0.01$, Fig. 3B, respectively).

The association between the number of food markets and COVID-19 cases and mortality persisted when cases $\left(R^{2}=0.25 ; r=0.49 ; p<0.01\right)$ and deaths $\left(R^{2}=0.33 ; r=\right.$ $0.58 ; p<0.01$ ) were adjusted by population density. Furthermore, the case fatality rate was associated with an increased number of food markets ( $p<0.05$; Fig. 3C).

However, the number of food markets per district did not correlate with $\mathrm{PM}_{2.5}\left(\mu \mathrm{g} / \mathrm{m}^{3}\right) \quad(\mathrm{Y}=0.033 \mathrm{x}+21.05$; $\left.R^{2}=0.04 ; r=0.21 ; p>0.05\right)$. This suggests that $\mathrm{PM}_{2.5}$ and the number of food markets were independently associated with the spread of COVID-19. Moreover, a higher number of food markets was associated with an increased case-fatality rate, whereas a higher $\mathrm{PM}_{2.5}$ level did not increase the fatality rate (data not shown).

In general, the higher the number of food markets per district was, the higher was the incidence of COVID-19/ population density $\left(\mathrm{y}=0.03 \times{ }^{0.63} ; r=0.58 ; p<0.01\right)$. Additionally, the higher the number of food markets per district was, the higher was the COVID-19 mortality/ population density $100\left(\mathrm{Y}=0.04 \times \times^{0.73} ; r=0.66 ; p<\right.$ 0.001; data not shown).

Increasing $\mathrm{PM}_{2.5}$ levels were not associated with specific age at infection, death, or age at death/age at infection in COVID-19 ( $p>0.05$; Fig. 4A, B, and C).

GLM analysis showed that increasing levels of $\mathrm{PM}_{2.5}$ $\left(\mu \mathrm{g} / \mathrm{m}^{3}\right)$ in the previous years $(2012-2016)$ were associated with a higher incidence of COVID-19 in the 24 districts of Lima included in the study. This was also observed after adjusting for the sex ratio, age at onset, and number of food markets per district (Table 2). Table 3 shows that $\mathrm{PM}_{2.5}$ was associated with death/ population density after controlling for age, sex and number of food markets. In contrast, after controlling for different variables, the case fatality rate (deaths/ cases*100) was not associated with increasing levels of $\mathrm{PM}_{2.5} \quad$ (Table 4). Additionally, environmental temperature and relative humidity were not associated with cases of COVID-19/density population or with death due to COVID-19 (Supplementary Table 3), whereas temperature was inversely associated with CFR *100 (Supplementary Table 3).

\section{Discussion}

This study showed that exposure to high levels of $\mathrm{PM}_{2.5}$ in the years preceding the COVID-19 pandemic is associated with a higher incidence of COVID-19 infection and mortality due but not the case fatality rate (Deaths/ cases*100) in Metropolitan Lima, a city that is considered one of the most polluted in Latin America [13]. The findings suggest that the current incidence of COVID-19 is associated with chronic exposure to air pollution. Furthermore, the association was maintained after controlling for population density, age, sex and number of food markets.

This is an important finding that explains why cases of COVID-19 increased in Lima despite Peru having one of the earliest COVID-19 lockdowns in Latin America, applying a quarantine, with many activities closed (schools, universities, churches, ban of public events), soon after the first case of COVID-19 was detected.

In Peru, some specific factors might contribute to the spread of COVID-19 during quarantine. These include the easy availability of food markets, banks, and public transport. In Peru, food markets remained open during the quarantine period to ensure food availability for the population. We believe most of the contagions at this time were due to the congregation of people in these food markets. According to the findings of this study, there were higher numbers of cases and deaths in districts where there were more markets. This may explain the high spread of COVID-19 in Lima, in a situation in which individuals are susceptible to the virus by previous exposure to air pollutants.

A previous systematic analysis showed that the incidence of and risk of morbidity and mortality from COVID-19 increase with chronic and acute exposure to air pollution, particularly to $\mathrm{PM}\left(\mathrm{PM}_{2.5}\right.$ and $\left.\mathrm{PM}_{10}\right)$ and nitrogen dioxide [8, 22-24].

Values of $\mathrm{PM}_{2.5}$ ranged from 14.50 to $41.69 \mu \mathrm{g} / \mathrm{m}^{3}$ for all districts, which were all higher than the annual mean value declared by the WHO $\left(10 \mu \mathrm{g} / \mathrm{m}^{3}\right)$. Thus, as it was previously shown that $\mathrm{PM}_{2.5}$ is associated with an increasing risk for respiratory infectious diseases [16], the 
Table 1 Sex-stratified differences in age at COVID-19 confirmation and at death due to COVID-19 at the national level and in the province of Lima

\begin{tabular}{lll}
\hline Statistical variables & Age among men (years) & Age among women (years) \\
\hline Cases at the country level & $42.93 \pm 16.88$ & $43.17 \pm 17.69^{*}$ \\
& $(n=130,333)$ & $(n=90,256)$ \\
Cases at the Lima level & $43.01 \pm 16.90$ & $43.67 \pm 17.96^{*}$ \\
& $(n=72,992)$ & $(n=50,613)$ \\
Deaths at the country level & $64.51 \pm 13.85$ & $66.68 \pm 14.91^{*}$ \\
& $(n=4047)$ & $(n=1643)$ \\
Deaths at the Lima level & $64.43 \pm 14.12$ & $67.37 \pm 14.47^{*}$ \\
& $(n=1695)$ & $(n=687)$ \\
\hline
\end{tabular}

Data are the mean \pm SD

${ }^{*} p<0.01$, with regard to values for men

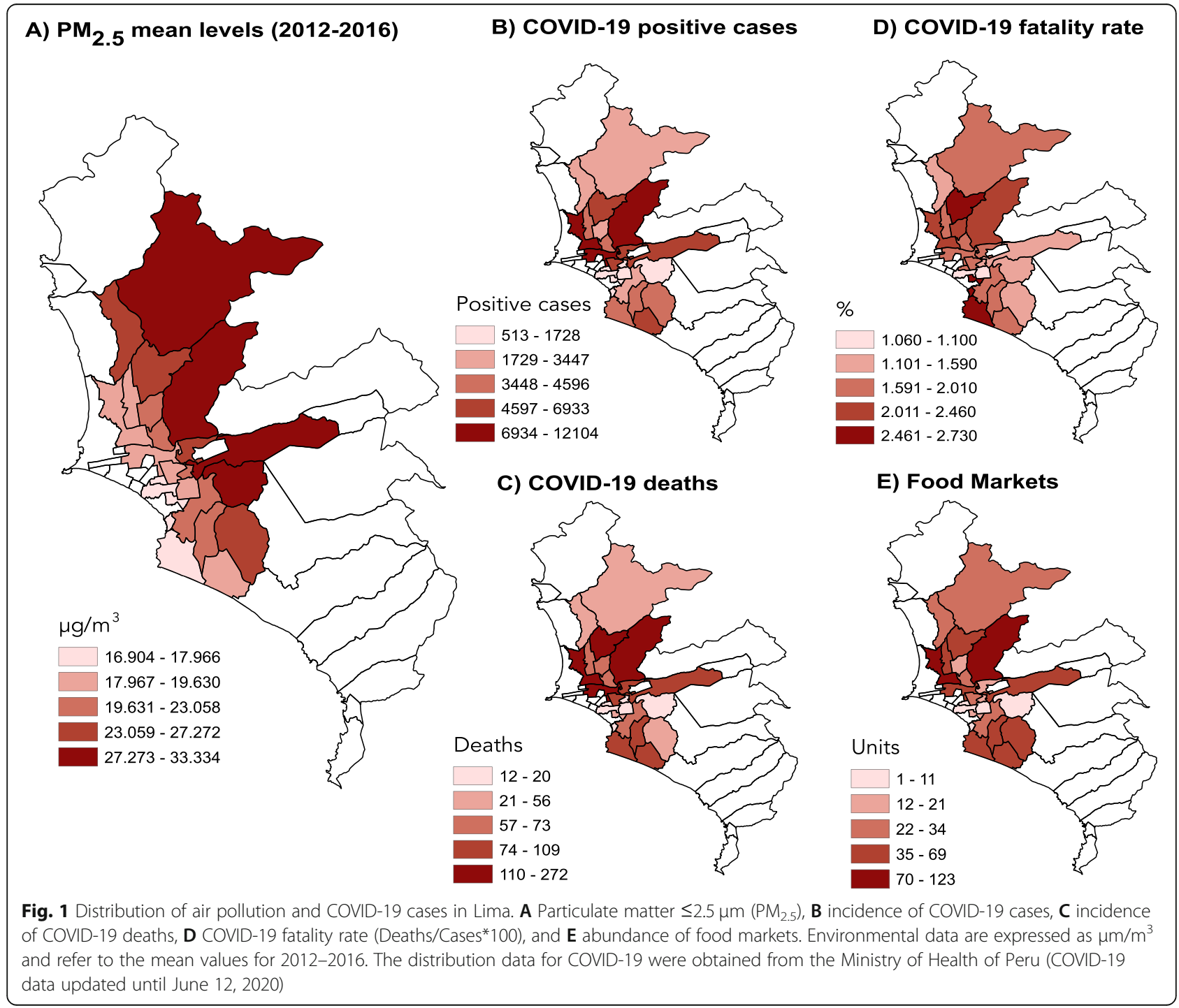




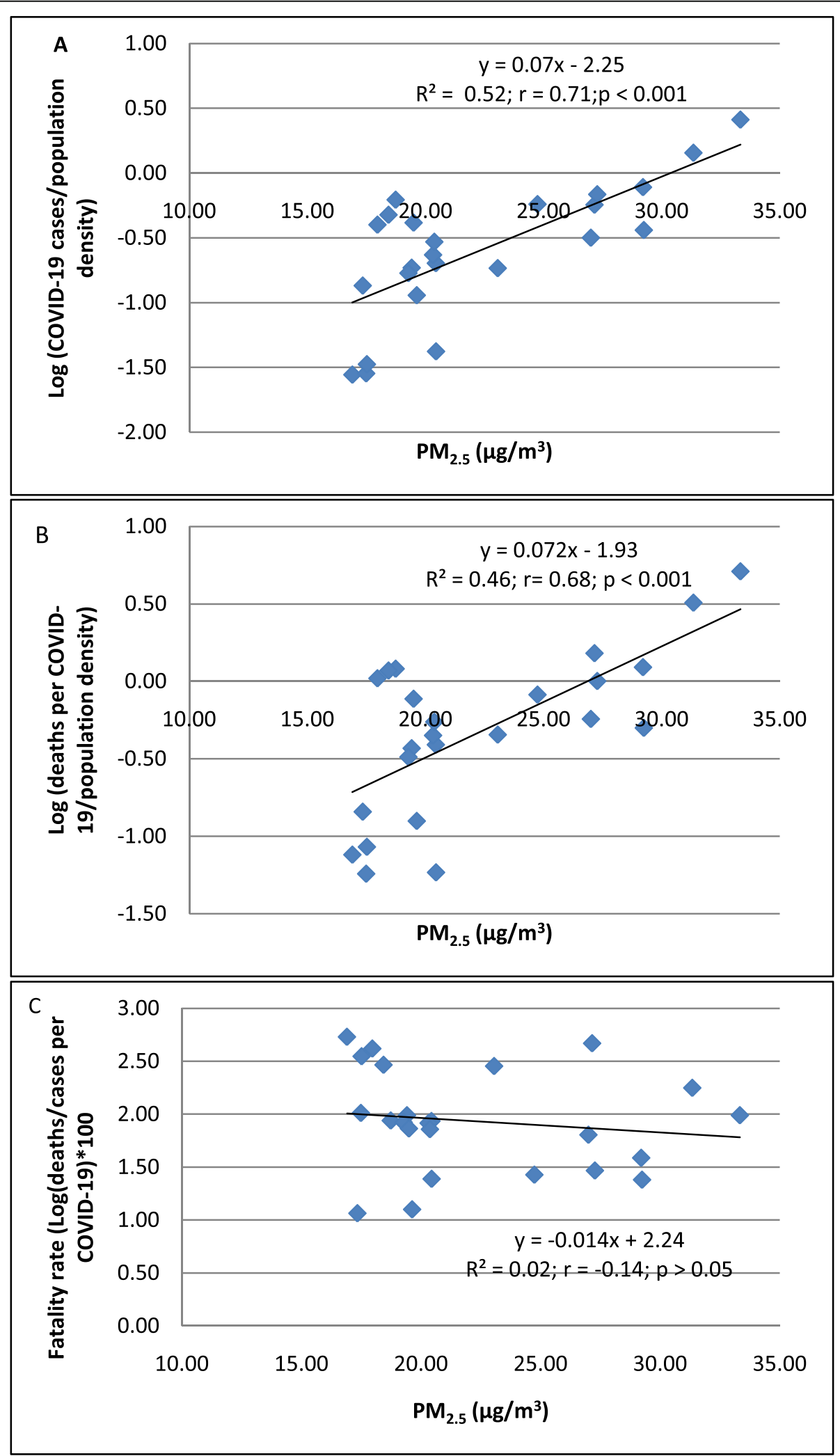

Fig. 2 The association between PM 2.5 and Log (cases of COVID-19/population density) (A), Log (deaths per COVID-19/population density) (B), and fatality rates ${ }^{*} 100(\mathbf{C})$ in 24 districts of Metropolitan Lima. The population of the district was ascertained from the values reported in the census of 2017. This number was not corrected based on the estimation of growth 

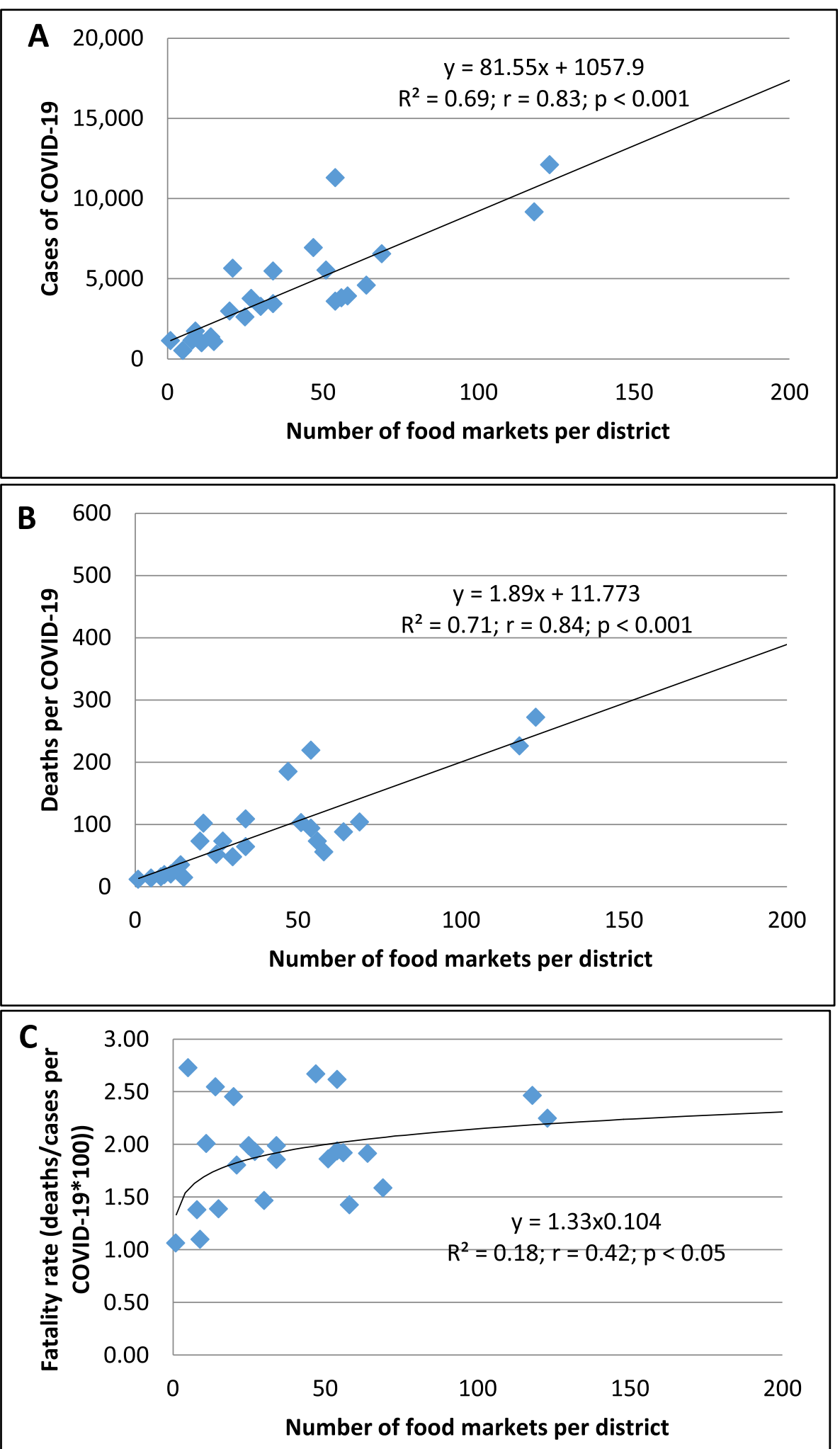

Fig. 3 The association between the number of food markets per district and cases of COVID-19 (A), deaths per COVID-19 (B), and fatality rates *100 (C) in 24 districts of Metropolitan Lima 


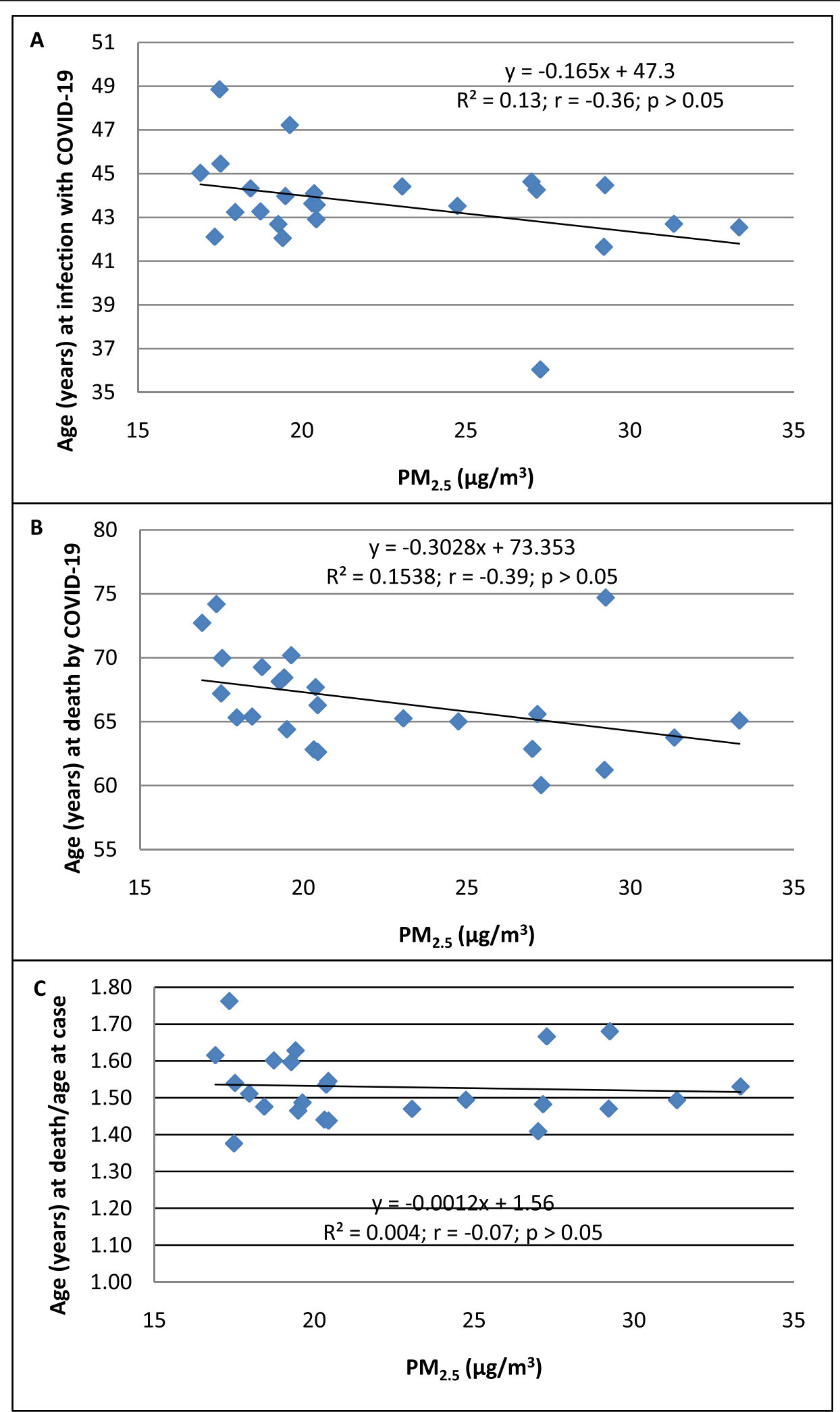

Fig. 4 The association between $\mathrm{PM}_{2.5}\left(\mu \mathrm{g} / \mathrm{m}^{3}\right)$ and age (years). A Age at COVID-19 diagnosis, B age at death due to COVID-19, and C age at death/age at confirmation of COVID-19 in 24 districts of Metropolitan Lima. The population of the district was ascertained from the values reported in the census of 2017. This number was not corrected based on the estimation of growth 
Table 2 Association between COVID-19 case/population density and previous PM 2.5 concentrations in 24 districts of Lima

\begin{tabular}{|c|c|c|c|c|c|c|}
\hline \multirow{2}{*}{$\begin{array}{l}\text { COVID-19 case/population density } \\
\mathrm{PM}_{2.5}\end{array}$} & \multirow{2}{*}{$\begin{array}{l}\text { Crude coefficient } \\
0.083^{* *}\end{array}$} & \multicolumn{2}{|l|}{$95 \% \mathrm{Cl}$} & \multirow{2}{*}{$\begin{array}{l}\text { Adjusted coefficient } \\
0.070^{* *}\end{array}$} & \multicolumn{2}{|l|}{$95 \% \mathrm{Cl}$} \\
\hline & & 0.050 & 0.115 & & 0.034 & 0.107 \\
\hline Sex ratio & $-3.133^{*}$ & -5.329 & -0.937 & -2.157 & -5.127 & 0.812 \\
\hline Age & -0.080 & -0.181 & 0.021 & 0.047 & -0.064 & 0.158 \\
\hline Food markets & 1.269 & -0.259 & 2.796 & 0.242 & -0.973 & 1.457 \\
\hline
\end{tabular}

The model was adjusted for $\mathrm{PM}_{2.5}$ level, sex ratio (female cases: male cases), and food markets (number of food markets per district and age [years] at the COVID19 diagnosis). Data for the $\mathrm{PM}_{2.5}$ level $\left(\mu \mathrm{g} / \mathrm{m}^{3}\right)$ correspond to the average data per district obtained daily from 2012 to 2016

${ }^{*} p<0.05 ;{ }^{* *} p<0.01$

present situation with the spread of COVID-19 demonstrates an increasing trend. Although we assessed the association with long-term $\mathrm{PM}_{2.5}$ exposure, the impact of short-term exposure needs to be addressed in further research.

Analysis of the distribution of COVID-19 cases worldwide demonstrates remarkable asymmetry with respect to countries/regions $[25,26]$. This is exactly the pattern that we observed in Metropolitan Lima. For the 24 districts assessed, those with higher $\mathrm{PM}_{2.5}$ concentrations during 2012-2016 showed a higher COVID-19 incidence than did those with lower concentrations of pollutants (Supplementary Table 2). Nationwide, 220,749 cases and 6308 deaths due to COVID-19 have been reported since the first case. Lima has $58.3 \%$ of the national cases and $38 \%$ of deaths, though Lima represents only $28 \%$ of the total Peruvian population.

Human pathogenic coronaviruses, which include SARS-CoV-2, which is responsible for COVID-19, bind to target cells through the angiotensin-converting enzyme 2 (ACE2) receptor, which is expressed by epithelial cells of the lung, intestine, kidney, and blood vessels [27]. It is possible that $\mathrm{PM}_{2.5}$ induces elevated ACE2 activity.

Additionally, active cigarette smoking upregulates ACE-2 expression in the lower airways, which may partially explain the increased risk of severe COVID-19 in these populations [28]. If air pollutants act similarly to the agents released during smoking, it is probable that individuals with chronic exposure to these compounds would have low ACE-2 activity or greater susceptibility to the infection [29].

This study in Metropolitan Lima that used $\mathrm{PM}_{2.5}$ data from 2012 and 2016 for 24 districts showed that the case fatality rate did not increase with increasing values of $\mathrm{PM}_{2.5}$. This is an interesting finding because crude analysis of the data showed a higher rate of death when $\mathrm{PM}_{2.5}$ concentrations are higher. However, when the data were calculated as the number of COVID-19 deaths/number of cases (case-fatality rate), there was no observable association with $\mathrm{PM}_{2.5}$. Regardless, the results suggest that $\mathrm{PM}_{2.5}$ does not affect the case fatality rate. This agrees with data observed in New York after shortterm exposure to air pollutants [6].

The national COVID-19 case fatality rate was $2.58 \%$, and the rate was $1.93 \%$ for Lima. The higher rate in the rest of Peru with respect to Lima may reflect deficiencies in the healthcare system in the different provinces. In addition, the COVID-19 case fatality rate was higher in men and increased with age, thus confirming previous results [30].

On average, the age at infection was approximately 42 years in Peru, and it is possible that the age at infection will decrease after the end of quarantine. This is because more young people will be exposed.

At national and province levels (Lima), age at infection was 20 years younger than age at death due to COVID19. This higher mortality risk for older people has already been reported [31, 32]. In our study, the association between older age and COVID-19 mortality risk was unaffected by increasing levels of $\mathrm{PM}_{2.5}$, suggesting that the factors that explain the higher mortality risk with age are independent of $\mathrm{PM}_{2.5}$ exposure. In fact, $\mathrm{PM}_{2.5}$ did not modify the COVID-19 case fatality rate in Lima.

Lima has an average elderly population of $13 \%$ and under 19 years of age population of $22 \%$. Districts of the suburbs (Ate, Puente Piedra, Carabayllo, VES and VMT)

Table 3 Association between COVID-19 death/population density and previous $\mathrm{PM}_{2.5}$ concentrations in 24 districts of Lima

\begin{tabular}{|c|c|c|c|c|c|c|}
\hline \multirow{2}{*}{$\begin{array}{l}\text { COVID-19 deaths/population density } \\
\mathrm{PM}_{2.5}\end{array}$} & \multirow{2}{*}{$\begin{array}{l}\text { Crude coefficient } \\
0.0016^{* *}\end{array}$} & \multicolumn{2}{|l|}{$95 \% \mathrm{Cl}$} & \multirow{2}{*}{$\begin{array}{l}\text { Adjusted coefficient } \\
0.0014^{*}\end{array}$} & \multicolumn{2}{|l|}{$95 \% \mathrm{Cl}$} \\
\hline & & 0.0008 & 0.0023 & & 0.0006 & 0.0023 \\
\hline Sex ratio & 0.019 & -0.005 & 0.044 & 0.009 & -0.010 & 0.029 \\
\hline Age & -0.001 & -0.002 & 0.000 & 0.000 & -0.001 & 0.002 \\
\hline Food markets & 0.029 & -0.002 & 0.060 & 0.024 & -0.007 & 0.055 \\
\hline
\end{tabular}

The model was adjusted for $\mathrm{PM}_{2.5}$ level, sex ratio (female deaths: male deaths), and food markets (number of food markets per district and age [years] at the moments of death by COVID-19). Data for the $\mathrm{PM}_{2.5}$ level $\left(\mu \mathrm{g} / \mathrm{m}^{3}\right)$ correspond to the average data per district obtained daily from 2012 to 2016 ${ }^{*} p<0.05$; ${ }^{* *} p<0.01$ 
Table 4 Association between the COVID-19 case fatality rate and previous PM 2.5 concentrations in 24 districts of Lima

\begin{tabular}{|c|c|c|c|c|c|c|}
\hline \multirow{2}{*}{$\begin{array}{l}\text { COVID-19 fatality rate } \\
\mathrm{PM}_{2.5}\end{array}$} & \multirow{2}{*}{$\begin{array}{l}\text { Crude coefficient } \\
-0.014\end{array}$} & \multicolumn{2}{|l|}{$95 \% \mathrm{Cl}$} & \multirow{2}{*}{$\begin{array}{l}\text { Adjusted coefficient } \\
0.01\end{array}$} & \multicolumn{2}{|l|}{$95 \% \mathrm{Cl}$} \\
\hline & & -0.056 & 0.029 & & -0.047 & 0.068 \\
\hline Sex ratio & -0.303 & -2.569 & 1.963 & -1.956 & -5.207 & 1.293 \\
\hline Age & 0.043 & -0.049 & 0.135 & 0.035 & -0.039 & 0.11 \\
\hline Food markets & 1.082 & -0.257 & 2.422 & 0.0054 & -0.001 & 0.012 \\
\hline Population density & 0.00001 & $-6.21 e^{-06}$ & .000035 & 0.00003 & $-2.60 \mathrm{e}^{-06}$ & 0.00006 \\
\hline
\end{tabular}

The model was adjusted for $\mathrm{PM}_{2.5}$ level, sex ratio (female cases: male cases), age [years], and food markets (number of food markets per district and population density at the COVID-19 diagnosis). Data for the $\mathrm{PM}_{2.5}$ level $\left(\mu \mathrm{g} / \mathrm{m}^{3}\right)$ correspond to the average data per district obtained daily from 2012 to 2016 $p>0.05$

have the lowest elderly population and therefore more young people. The largest population (19-64 years) is similar in all districts, and those who move around the city for work, shopping, entertainment are the most exposed to infection [33].

There is evidence of the role of PM pollutants in COVID-19 transmission. $\mathrm{PM}_{2.5}$ and other small PM can act as disease vectors and facilitate airborne transmission of viable virus particles, which have been implicated in the spread of measles and SARS [34].

Social distancing is an important preventable measure to decrease the spread of COVID-19. This was demonstrated in 28 European countries, where the most likely point of change during the COVID-19 epidemic showed a dose-response association of the observed flattening of the epidemic curve with an increasing social distancing index (SDI). Countries in the highest SDI quartile achieved a statistically significant decline in the incidence and prevalence of the disease [34].

According to a recent report, social distancing measures that were adopted by the population in Brazil appeared to be effective, particularly when implemented in conjunction with the isolation of cases and quarantine of contacts [35].

In numerical simulations, three scenarios were compared in a city within Brazil: first was the vertical distancing policy, where only older people were distanced; the second involved the horizontal distancing policy where all age groups adhered to social distancing; and the third involved a control scenario in which no intervention was undertaken to distance people. Horizontal distancing, if applied with the same intensity in all age groups, significantly reduced the total number of infected people by "flattening the disease growth curve"; conversely, vertical distancing or no distancing did not have this effect [36].

Doubtless, social distancing measures appear to be the most effective intervention to slow the disease spread of COVID-19. Although studies unanimously confirm the mitigating effect of social distancing on disease spread, the reported effectiveness varies from $10 \%$ to a more than $90 \%$ reduction in the number of infections [34]. Changes in mobility in public places, such as retail and recreation centers (e.g., restaurants, cafes, theatres), grocery stores and pharmacies, transit hubs (e.g., airports, bus stations, subways), and parks are the most important determinants of the disease transmission rate [37].

It is well known that the highest risk of COVID-19 occurs prior to symptom onset. A recent paper provides evidence of the effectiveness of mask use, disinfection, and social distancing in the prevention of COVID-19 [38].

In this study, the number of markets was unrelated to the $\mathrm{PM}_{2.5}$ concentration, which suggests that both factors are independently associated with the spread of COVID-19. Moreover, after controlling for different variables, including the number of food markets, $\mathrm{PM}_{2.5}$ remained associated with the number of cases of COVID-19.

From a long-term perspective, a reduction in air contamination should be considered a part of the integrated approach for sustainable development, human health protection, and reducing the spread of a disease during an outbreak, epidemic, or pandemic. Nevertheless, although reducing air pollution is important to reduce morbidity and mortality due to different diseases, the findings of this study also suggest the importance of social isolation to reduce the incidence of COVID-19 [39]. The magnitude of contagion in food markets is an example that policies aimed at reducing crowding should be important for preventing the spread of COVID-19.

We did not find an association between environmental temperature and COVID-19 cases or deaths. However, CFR was inversely related to increased temperature. Other authors have also observed that temperature may not be a determinant inducing COVID-19 spread [40, 41]. Another study indicates that lower temperature may increase COVID-19 transmission, but there is no evidence that temperature affects the case fatality rate [42]. Humidity has been negatively associated with COVID19-related death [43]. Our study, however, showed no association between humidity and COVID-1 death. Further studies are required to clarify different results between countries.

The limitations of this study are a lack of data for the number of people attending food markets during the 
quarantine period. We were also unable to obtain data for people visiting banks and using public transportation within the same period. Data regarding for social distancing and the use of masks are also lacking.

The study makes a significant contribution to the literature because the findings indicate that past exposure to higher $\mathrm{PM}_{2.5}$ levels is associated with a higher incidence of COVID-19 disease and mortality. However, the case fatality rate did not increase with increases in $\mathrm{PM}_{2.5}$ levels. This study is different from other papers that discuss association between current pollution levels and pandemic intensity.

The findings of this study are generalizable to regions with similar population densities and $\mathrm{PM}_{2.5}$ levels in the setting of respiratory epidemics or future pandemics. The findings will be a support tool for decision-making regarding the country's health policy, as a study in which $\mathrm{PM}_{2.5}$ is associated based on district, age, sex, and food markets with the number of COVID-19 cases and mortality will allow us to rethink the measures used by the Peruvian government and other countries characterized by high air pollution.

In conclusion, the present study demonstrates that higher rates of spread of COVID-19 in Metropolitan Lima (Peru) are associated with previous long-term $\mathrm{PM}_{2.5}$ exposure. Men and older people were at higher risk of death due to COVID-19. Reduction in air pollution from a long-term perspective and social distancing are needed to prevent the spread of virus outbreaks. These results should be considered by officers of the government to be applied in health policies aimed at preventing or reducing epidemic viral spread. The strategies taken to confront the pandemic should also consider previous environmental indicators to intensify efforts in areas with higher air pollution.

\section{Abbreviations \\ ACE2: Angiotensin-converting enzyme 2; Cl: Confidence interval; COVID- 19: Coronavirus disease 2019; ${ }^{\circ} \mathrm{C}$ : Centigrade degree; GEOHealth: Global Environmental and Occupational Health; GLM: Generalized linear model;

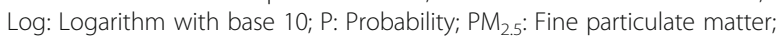 $\mathrm{PM}_{10}$ : Solid or liquid particles with diameter varying between 2.5 and $10 \mu \mathrm{m}$; $R^{2}$ : Coefficient of determination; r: Coefficient of Pearson; SARS: Severe acute respiratory syndrome; SARS-CoV-2: Severe acute respiratory syndrome coronavirus 2; SD: Standard deviation; SDI: Social distancing index; SENA MHI: National Service of Meteorology and Hydrology of Peru; SIDI SI: Decentralized Information System and Monitoring of Research; WHO: World Health Organization}

\section{Supplementary Information}

The online version contains supplementary material available at https://doi. org/10.1186/s12889-021-11232-7.

\section{Additional file 1.}

\section{Acknowledgments}

We thank our colleagues at the Ministry of the Environment (MINAM/ SENAMHI) for their collaboration throughout this project.

\section{Authors' contributions}

BW-A: idea, design and interpretation; EP: analysis of the data; VP: data analysis; VT: data analysis and manuscript preparation, JR: work with environmental dataset and interpretation; OS: environmental dataset, discussion. GFG, idea, design, manuscript writing and discussion. All authors approved the final version.

\section{Funding}

Bertha V. Vasquez-Apestegui, Vilma Tapia, Valeria M. Paz-Aparicio, Odon R. Sanchez-Ccoyllo and Gustavo F. Gonzales are supported by Grant U01TW010107 (1/2 Regional GEOHealth hub centered in Peru) from the National Institutes of Health (Fogarty Program). The content is solely the responsibility of the authors and does not necessarily represent the official views of the National Institutes of Health. This research did not receive any specific grant from funding agencies in the public, commercial, or not-forprofit sectors.

\section{Availability of data and materials}

The datasets generated and/or analyzed during the current study are available in the following repositories:

- Data of food markets: INEI repository:www.inei.gob.pe/media/ MenuRecursivo/publicaciones_digitales/Est/Lib1447/libro.pdf

- Data related to COVID-19: MINSA repository:https://www.datosabiertos. gob.pe/dataset/casos-positivos-por-covid-19-ministerio-de-salud-minsa https://www.datosabiertos.gob.pe/dataset/fallecidos-por-covid-19-ministeriode-salud-minsa

- Environmental data:

Data were obtained as a part of an agreement between SENAMHI and Universidad Peruana Cayetano Heredia as part of the Regional GEOHealth Hub centered in Peru. The datasets of predicted $\mathrm{PM}_{2.5}$ concentrations at 1$\mathrm{km}^{2}$ spatial resolution in Lima-Peru from 2010 to 2016 used during the study are available from the corresponding author upon reasonable request.

\section{Declarations}

\section{Ethics approval and consent to participate}

The study protocol was approved by the Institutional Committee for Ethics and Research of the Universidad Peruana Cayetano Heredia (SIDISI code: 202647). This research was a secondary database analysis and therefore did not involve direct contact with study participants. There is no identification of persons in the database, thereby guaranteeing the total confidentiality and anonymity of the data.

\section{Consent for publication}

All authors consent to the final version for publication.

\section{Competing interests}

The authors declare that they have no competing interests.

\section{Author details \\ ${ }^{1}$ High-Altitude Research Institute; Laboratories of Investigation and Development (LID), Department of Biological and Physiological Sciences, Faculty of Sciences and Philosophy, Universidad Peruana Cayetano Heredia, Av. Honorio Delgado 430, Lima, Peru. ${ }^{2}$ Laboratory of Endocrinology and Reproduction, Universidad Peruana Cayetano Heredia, Av. Honorio Delgado 430, Lima, Peru. ${ }^{3}$ National Meteorology and Hydrology Service (SENAMHI), Deputy Director of Evaluation of the Atmospheric Environment, Jr. Cahuide 785, Lima, Peru. ${ }^{4}$ Atmospheric Pollution Research Group, Professional Career of Environmental Engineering, Universidad Nacional Tecnológica de Lima Sur, Sector 3 Grupo 1A 03 - Cercado (Av. Central y Av. Bolivar), Lima, Peru.}

Received: 1 March 2021 Accepted: 7 June 2021

Published online: 16 June 2021

\section{References}

1. Halaji M, Farahani A, Ranjbar R, Heiat M, Dehkordi FS. Emerging coronaviruses: first SARS, second MERS and third SARS-CoV-2: epidemiological updates of COVID-19. Infez Med. 2020;28(Suppl. 1):6-17.

2. Kakodkar P, Kaka N, Baig MN. A comprehensive literature review on the clinical presentation, and management of the pandemic coronavirus 
disease 2019 (COVID-19). Cureus. 2020;12(4):e7560. Published 2020 Apr 6. https://doi.org/10.7759/cureus.7560.

3. Munayco CV, Tariq A, Rothenberg R, Soto-Cabezas GG, Reyes MF, Valle A, et al. Peru COVID-19 working group. Early transmission dynamics of COVID19 in a southern hemisphere setting: Lima-Peru: February $29^{\text {th }}-$ March $30^{\text {th }}$, 2020. Infect Dis Model. 2020;5:338-45. https://doi.org/10.1016/j.idm.2020.05. 001 PMID: 32399507; PMCID: PMC7215155.

4. Frontera A, Cianfanelli L, Vlachos K, Landoni G, Cremona G. Severe air pollution links to higher mortality in COVID-19 patients: the "double-hit" hypothesis. J Inf Secur. 2020;50163-4453(20):30285-1.

5. Frontera A, Martin C, Vlachos K, Sgubin G. Regional air pollution persistence links to COVID-19 infection zoning. J Inf Secur. 2020;S0163-4453(20):30173-0.

6. Liang D, Shi L, Zhao J, Liu P, Sarnat JA, Gao S, et al. Urban air pollution may enhance COVID-19 case-fatality and mortality rates in the United States. Innovation (N Y). 2020;1(3):100047. https://doi.org/10.1016/j.xinn.2020.100047 Epub 2020 Sep 21. PMID: 32984861; PMCID: PMC7505160.

7. Adhikari A, Yin J. Short-term effects of ambient ozone, $\mathrm{PM}_{2.5}$, and meteorological factors on COVID-19 confirmed cases and deaths in Queens, New York. Int J Environ Res Public Health. 2020;17(11):E4047. Published 2020 Jun 5. https://doi.org/10.3390/ijerph17114047.

8. Fattorini D, Regoli F. Role of the chronic air pollution levels in the Covid-19 outbreak risk in Italy. Environ Pollut. 2020;264:114732. https://doi.org/10.101 6/j.envpol.2020.114732.

9. Wang B, Eum K, Kazemiparkouhi F, Li C, Manjourides J, Pavlu V. The impact of long-term PM2.5 exposure on specific causes of death: exposureresponse curves and effect modification among 53 million U.S. Medicare beneficiaries. Environ Health. 2020;19:20. Published online 2020 Feb 17. https://doi.org/10.1186/s12940-020-00575-0.

10. Hoek G, Krishnan RM, Beelen R, Peters A, Ostro B, Brunekreef B, et al. Longterm air pollution exposure and cardio-respiratory mortality: a review. Environ Health. 2013;12:43. Published online 2013 May 28. https://doi.org/1 $0.1186 / 1476-069 X-12-43$.

11. Sanyal S, Rochereau T, Maesano CN, Com-Ruelle L, Annesi-Maesano I. Longterm effect of outdoor air pollution on mortality and morbidity: a 12-year follow-up study for metropolitan France. Int J Environ Res Public Health. 2018:Nov. 15(11):2487. Published online 2018 Nov 8. https://doi.org/10.3390/ ijerph15112487.

12. Bris-Redón A, Belenguer-Sapiña C, Serrano-Aroca A. A city-level analysis of air pollution, climate and COVID-19 early spread during the Spanish lockdown. medRxiv. 2020:2020.08.09.20171041. https://doi.org/10.1101/2020. 08.09.20171041.

13. Gonzales GF, Steenland K. Environmental health in Peru: outdoor and indoor air contamination. Pan Am J Public Health. 2014;36(2):141.

14. Iuliano AD, Roguski KM, Chang HH, Muscatello DJ, Palekar R, Tempia S, et al. Global Seasonal Influenza-associated Mortality Collaborator Network. Estimates of global seasonal influenza-associated respiratory mortality: a modelling study. Lancet. 2018;391(10127):1285-300. https://doi.org/10.1016/ S0140-6736(17)33293-2 Epub 2017 Dec 14. Erratum in: Lancet. 2018 Jan 19;: PMID: 29248255; PMCID: PMC5935243.

15. Ciencewicki J, Jaspers I. Air pollution and respiratory viral infection. Inhal Toxicol. 2017;19(14):1135-46. https://doi.org/10.1080/08958370701665434.

16. Davila Cordova JE, Aguirre VT, Apestegui W, Ibarguen LO, Vu BN, Steenland $\mathrm{K}$, et al. Correction to: Association of PM2.5 concentration with health center outpatient visits for respiratory diseases of children under 5 years old in Lima, Peru. Environ Health. 2020;19(1):11. https://doi.org/10.1186/s12940020-0569-0 Erratum for: Environ Health. 2020 Jan 15;19(1):7. PMID: 32000797; PMCID: PMC6990522.

17. Silva J, Rojas J, Norabuena M, Molina C, Toro RA, Leiva-Guzmán MA. Particulate matter levels in a south American megacity: the metropolitan area of Lima-Callao, Peru. Environ Monit Assess. 2017;189(12):635. https:// doi.org/10.1007/s10661-017-6327-2 PMID: 29134287.

18. Dutheil F, Baker JS, Navel V. COVID-19 as a factor influencing air pollution? Environ Pollut. 2020;263(A):114466. https://doi.org/10.1016/j.envpol.202 0.114466 .

19. Ma CJ, Kang GU. Air quality variation in Wuhan, Daegu, and Tokyo during the explosive outbreak of COVID-19 and its health effects. Int J Environ Res Public Health. 2020;17(11):E4119. https://doi.org/10.3390/ijerph17114119.

20. SENAMHI. Informe Vigilancia de la calidad del aire en el área Metropolitana de Lima y Callao. 2020.

21. Vu BN, Sánchez O, Bi J, Xiao Q, Hansel NN, Checkley W, et al. Developing an advanced PM 2.5 exposure model in Lima, Peru. Remote Sens. 2019;11(6):641. https://doi.org/10.3390/rs1 1060641 Epub 2019 Mar 16. PMID: 31372305; PMCID. PMC6671674.

22. Félix-Arellano EE, Schilmann A, Hurtado-Díaz M, Texcalac-Sangrador JL, Riojas-Rodríguez H. Quick review: air pollution and morbidity-mortality by COVID-19. Salud Pública Mex. 2020. https://doi.org/10.21149/11481.

23. Ogen Y. Assessing nitrogen dioxide (NO2) levels as a contributing factor to coronavirus (COVID-19) fatality. Sci Total Environ. 2020;726:138605. https:// doi.org/10.1016/j.scitotenv.2020.138605.

24. Bashir MF, Ma BJ, Bilal, Komal B, Bashir MA, Farooq TH, et al. Correlation between environmental pollution indicators and COVID-19 pandemic: a brief study in Californian context. Environ Res. 2020;187:109652. https://doi. org/10.1016/j.envres.2020.109652 Epub 2020 May 13. PMID: 32405084; PMCI D: PMC7219392

25. Fronza R, Lusic M, Schmidt M, Lucic B. Spatial-temporal variations in atmospheric factors contribute to SARS-CoV-2 outbreak. Viruses. 2020;12(6): E588. https://doi.org/10.3390/v12060588.

26. Sarmadi M, Marufi N, Kazemi Moghaddam V. Association of COVID-19 global distribution and environmental and demographic factors: an updated three-month study [published online ahead of print, 2020 May 29]. Environ Res. 2020;188:109748. https://doi.org/10.1016/j.envres.2020.1 09748.

27. Wang $Y$, Tian $H$, Zhang $L$, Zhang $M$, Guo $D$, Wu W, et al. Reduction of secondary transmission of SARS-CoV-2 in households by face mask use, disinfection and social distancing: a cohort study in Beijing, China. BMJ Glob Health. 2020;5(5):e002794. https://doi.org/10.1136/bmjgh-2020-002794.

28. Leung JM, Yang CX, Tam A, Shaipanich T, Hackett TL, Singhera GK, et al. ACE-2 expression in the small airway epithelia of smokers and COPD patients: Implications for COVID-19. Eur Respir J. 2020;55(5). https://doi.org/1 0.1183/13993003.00688-2020.

29. Ma JH, Song SH, Guo M, Zhou J, Liu F, Peng L, et al. Long-term exposure to PM2.5 lowers influenza virus resistance via down-regulating pulmonary macrophage Kdm6a and mediates histones modification in IL-6 and IFN- $\beta$ promoter regions. Biochem Biophys Res Commun. 2017;493(2):1122-8. https://doi.org/10.1016/j.bbrc.2017.09.013 Epub 2017 Sep 5. PMID: 28887033.

30. Palaiodimos L, Kokkinidis DG, Li W, Karamanis D, Ognibene J, Arora S, et al. Severe obesity, increasing age and male sex are independently associated with worse in-hospital outcomes, and higher in-hospital mortality, in a cohort of patients with COVID-19 in the Bronx, New York. Metabolism. 2020; 108:154262. https://doi.org/10.1016/j.metabol.2020.154262.

31. Cesari M, Montero-Odasso M. COVID-19 and older adults. Lessons learned from the Italian epicenter. Can Geriatr J. 2020;23(1):155-9. https://doi.org/10. 5770/cgj.23.445.

32. Chen L, Yu J, He W, Chen L, Yuan G, Dong F, et al. Risk factors for death in 1859 subjects with COVID-19. Leukemia. 2020;34(8):2173-83. https://doi. org/10.1038/s41375-020-0911-0.

33. INEl. Sistema Estadistico Nacional. Peru Compendio Estadistico. 2017.

34. Sharma AK, Balyan P. Air pollution and COVID-19: Is the connect worth its weight? Indian J Public Health. 2020;64((Supplement)(Suppl.)):S132-4. https://doi.org/10.4103/ijph.IJPH_466_20.

35. Vokó Z, Pitter J. The effect of social distance measures on COVID-19 epidemics in Europe: an interrupted time series analysis. Geroscience. 2020: 1-8. https://doi.org/10.1007/s11357-020-00205-0.

36. Aquino EML, Silveira IH, Pescarini JM, Aquino R, Souza-Filho JA, Rocha AS, et al. Social distancing measures to control the COVID-19 pandemic: potential impacts and challenges in Brazil. Cien Saude Colet. 2020;25(suppl 1):2423-46. https://doi.org/10.1590/1413-81232020256.1.10502020 English, Portuguese . Epub 2020 Apr 22. PMID: 32520287.

37. Duczmal LH, Almeida ACL, Duczmal DB, Alves CRL, Magalhães FCO, Lima MS, et al. Vertical social distancing policy is ineffective to contain the COVID-19 pandemic. Cad Saude Publica. 2020;36(5):e00084420. https://doi. org/10.1590/0102-311×00084420

38. Denle D, Eryarsoy E, Davazdahemami B. No place like home: cross-national data analysis of the efficacy of social distancing during the COVID-19 pandemic. JMIR Public Health Surveill. 2020;6(2):e19862. https://doi.org/10.21 96/19862.

39. Wang Y, Shang J, Graham R, Baric RS, Li F. Receptor recognition by novel coronavirus from Wuhan: an analysis based on decade-long structural studies of SARS. J Virol. 2020:94(7). https://doi.org/10.1128/JVI.00127-20.

40. Shahzad K, Shahzad U, lqbal N, Shahzad F, Fareed Z. Effects of climatological parameters on the outbreak spread of COVID-19 in highly affected regions of Spain. Environ Sci Pollut Res Int. 2020;27(31): 
39657-66. https://doi.org/10.1007/s11356-020-10551-3 Epub 2020 Aug 22. PMID: 32827296; PMCID: PMC7442890.

41. Iqbal N, Fareed Z, Shahzad F, He X, Shahzad U, Lina M. The nexus between COVID-19, temperature and exchange rate in Wuhan city: new findings from partial and multiple wavelet coherence. Sci Total Environ. 2020;729: 138916. https://doi.org/10.1016/j.scitotenv.2020.138916 Epub 2020 Apr 22. PMID: 32388129; PMCID: PMC7194511.

42. Hassan MM, El Zowalaty ME, Khan SA, Islam A, Nayem MRK, Järhult JD. Role of environmental temperature on the attack rate and case fatality rate of Coronavirus Disease 2019 (COVID-19) pandemic. Infect Ecol Epidemiol. 2020; 10(1):1792620. https://doi.org/10.1080/20008686.2020.1792620 PMID: 32944163; PMCID: PMC7480504.

43. Fareed Z, lqbal N, Shahzad F, Shah SGM, Zulfiqar B, Shahzad K, et al. Covariance nexus between COVID-19 mortality, humidity, and air quality index in Wuhan, China: new insights from partial and multiple wavelet coherence. Air Qual Atmos Health. 2020:1-10. https://doi.org/10.1007/s11869-020-0084 7-1 Epub ahead of print. PMID: 32837610; PMCID: PMC7279636.

\section{Publisher's Note}

Springer Nature remains neutral with regard to jurisdictional claims in published maps and institutional affiliations.

\section{Ready to submit your research? Choose BMC and benefit from:}

- fast, convenient online submission

- thorough peer review by experienced researchers in your field

- rapid publication on acceptance

- support for research data, including large and complex data types

- gold Open Access which fosters wider collaboration and increased citations

- maximum visibility for your research: over $100 \mathrm{M}$ website views per year

At $\mathrm{BMC}$, research is always in progress.

Learn more biomedcentral.com/submissions 